\title{
Examining of Published Articles with Respect to Statistical Errors in Medical Sciences
}

\author{
Ilker ERCAN ${ }^{1}$, Pinar G. KARADENIZ ${ }^{1}$, Sengul CANGUR², Guven OZKAYA¹, Hakan DEMIRTAS ${ }^{3}$
}

${ }^{1}$ Uludag University Faculty of Medicine, Biostatistics, Bursa, TURKEY

${ }^{2}$ Duzce University Faculty of Medicine, Biostatistics, Duzce, TURKEY

${ }^{3}$ University of Illinois School of Public Health, Epidemiology and Biostatistics, Chicago, USA

\begin{abstract}
Researchers who do not have adequate statistical knowledge commit a wide range of critical errors with regard to the design, execution,analysis, presentation and interpretation of their studies. The aim of the present work is to examine the statistical errors of scientific articles. Cross sectional study. Methods: Ninety-five articles published in either Science Citation Index (SCI) or (Science Citation Index-Expanded) SCI-E journals, 122 articles published in non-SCl or non-SCI-E journals were included in this study. The articles were chosen from among those indexed in the PubMed and Bioline databases between the years 2004 and 2010 , inclusively. A total of 217 articles had at least one statistical error. The most frequently encountered statistical error was "errors in summarizing data" for articles published in the journals indexed in SCl or SCl-E, as well as non-SCl or non-SCl-E journals. For errors involving "use of an incorrect test" and "statistical symbol errors", there was a statistically significant difference between articles published in journals indexed in SCl or SCl-E and non-SCl or non-SCl-E journals; this difference favored the former. Some action should be taken by researchers and editors to prevent the introduction of statistical errors into scientific publications. Researchers (i) should have a basic statistical knowledge, (ii) should consult a biostatistician at the planning, analyzing, interpreting and reporting stages of a study. Furthermore, editors should send studies that have been submitted to their journal to a biostatistician during the review process.
\end{abstract}

Keywords: Statistical errors, Statistical review, Medical articles

\section{ÖZET}

\section{Tıp Bilimlerinde Yayınlanan Makalelerin İstatistiksel Hatalar Bakımından İncelenmesi}

İstatistik bilgisi yeterli olmayan araştırmacılar; çalışmalarının tasarımında, yürütülmesinde, analizinde, sunumunda ve yorumlanmasında bir takım önemli hatalar yapmaktadırlar. Bu çalışmanın amacı, bilimsel makalelerdeki istatistiksel hataları incelemektir. Science Citation Index (SCl) ya da (Science Citation Index-Expanded) SCl-E indekslerinde yer alan dergilerde yayınlanan 95 makale ile, bu indekslerde yer almayan dergilerde yayınlanan 122 makale çalışmaya dahil edilmiştir. Makaleler 2004 ve 2010 yılları arasında PubMed ve Bioline veri tabanlarında yer alan makaleler arasından seçilmiştir. Toplam 217 makalenin tümünde en az bir istatistiksel hata olduğu görülmüştür. Hem SCl ya da SCl-E indeksli dergilerde hem de bu indeklerde yer almayan dergilerde yayınlanan makalelerde en sık karşılaşılan hata, "verilerin özetlenmesinde yapılan hatalar" dır. SCI ya da SCl-E indeksli dergilerde yayınlanan makalerler ile bu indekslerde yer almayan dergilerde yayınlanan makaleler arasında; "yanlış bir test kullanımı" ve "istatistiksel sembol hataları" konusunda istatistiksel olarak anlamlı bir fark elde edilmiştir. Bilimsel yayınlarda istatistiksel hatalarla karşılaşmamak için araştırmacılar tarafından bir takım önlemler alınmalıdır. Araştırmacılar (i) temel istatistik bilgisine sahip olmalıdır, (ii) bir çalışmanın planlama, analiz, yorumlama ve raporlama aşamalarında bir biyoistatistik uzmanına danışmalıdır. Ayrıca, editörler, dergilerine gönderilen çalışmaların hakem incelemesi sürecinde çalışmaları bir biyoistatistik uzmanına göndermelidir.

Anahtar Kelimeler: İstatistiksel hatalar, İstatistiksel inceleme, Tıbbi makaleler 


\section{INTRODUCTION}

Researchers who do not have adequate statistical knowledge commit a wide range of critical errors with regard to the design, execution, analysis, presentation and interpretation of their studies. Accordingly, researchers who lack the necessary statistical competence and dexterity seem to experience difficulties in grasping the topics under consideration, which leads to inaccurate, incomplete, and suboptimal opinions. On a related note, physicians, who represent a consequential subset of researchers, should follow up on intellectual output relevant to their specialization and participate in scientific meetings. Considering the fact that the majority of journal articles and conference proceedings are supplemented by statistical tools, even physicians who do not conduct active research and whose scientific engagement is limited to reading should develop an acceptable level of statistical comprehension. ${ }^{1,2}$

In scientific studies, statistical analysis facilitates a decision-making process that, for the purpose of inference, is free from subjective judgments. Statistical practices should be employed at all stages of research, from planning to the end, to draw precise, plausible conclusions and to obtain reliable, defensible results. Unfortunately, statistical errors of varying degrees of seriousness appear in the scholarly world. One can envision a long list of factors that contribute to this phenomenon, but it all boils down to researchers' lack of a solid statistical background. ${ }^{3,4}$ In the medical sciences, the frequency and magnitude of errors have reached a level that promotes the examination of statistical errors in published articles as a self-contained research topic. In this context, premonitory reviews, as well as articles that assess statistical errors appearing in practice, have been published. ${ }^{2,5-11}$ Errors due to substandard research are typically associated with ethical implications, including the misuse of resources, the exposure of patients to unjustified risks and inconveniences and the consequences of publishing misleading results.

The aim of the present work is the examination of statistical errors in scientific articles in two ways: (i) with respect to the distribution of errors across similar studies and (ii) with respect to the relative error rates in published articles in journals that are indexed in science citation index (SCI) or science citation index-expanded (SCI-E) compared to nonSCI or non-SCI-E journals.

\section{MATERIALS AND METHODS}

The ratio of the published papers with statistical errors ranges between $0.26(50 / 195)$ and $0.87(48 / 55)$ (median= 0.57). , $, 4-5,7-8,11$ In our work, this information was considered for the calculation of sample size, which turned out to be $n=161$ when the significance level is $\alpha=0.05$, the margin of error is $d=$ 0.10 , and the ratio of articles with statistical errors is $p=0.57$. The number of articles examined for statistical errors were ranged between 55 and 195 in similar studies. ${ }^{2,4-5,-7-8,11}$ Although 161 articles were adequate for our investigation, in an attempt to conduct a more comprehensive study than the similar ones, 217 articles were examined.

Ninety-five articles published in either SCI or SCI-E journals and 122 articles published in nonSCI or non-SCI-E journals were included in this study. The articles were chosen from among those indexed in the PubMed and Bioline databases between the years 2004 and 2010, inclusively. The reference list of a randomly selected article was used for randomization in article selection. The first article that was ranked as first in the reference list with respect to the author name in relevant years was selected, and then this process was repeated for the first authors of other articles in the reference list. After the last article in the reference list was used for selection, by going back to the beginning of the reference list the second authors' name were employed as the key word for selection. The names of authors were entered into the search engines of these databases. Randomization was accomplished by repeating the process in article selection. Sample size was considered as approximately equal according to years. The frequencies and percentages of the examined published articles by years are given in Table 1 .

In our study, the selected articles were examined by allocating articles among research team members with respect to the type of statistical errors. The examined statistical errors were classified following the description appeared in Ercan et al. and 


\begin{tabular}{|c|c|c|c|}
\hline Years & $\begin{array}{l}\text { Indexed at SCI-SCIE } \\
\% \text { (n) }\end{array}$ & $\begin{array}{l}\text { Non-SCI or Non-SCIE } \\
\% \text { (n) }\end{array}$ & $\begin{array}{l}\text { Total } \\
\%(n)\end{array}$ \\
\hline 2010 & $10.53(10)$ & $15.57(19)$ & $13.36(29)$ \\
\hline 2009 & $16.84(16)$ & $13.11(16)$ & 14.75 (32) \\
\hline 2008 & $16.84(16)$ & $13.11(16)$ & $14.75(32)$ \\
\hline 2007 & $11.58(11)$ & $16.39(20)$ & 14.29 (31) \\
\hline 2006 & 13.68 (13) & 15.57 (19) & 14.75 (32) \\
\hline 2005 & $16.84(16)$ & $12.30(15)$ & $14.29(31)$ \\
\hline 2004 & $13.68(13)$ & $13.93(17)$ & $13.82(30)$ \\
\hline Total & 100 (95) & 100 (122) & $100(217)$ \\
\hline
\end{tabular}

Ercan and Demirtas. ${ }^{4,12}$ Of note, errors assessed by each researcher were confirmed by all members of the research team. Therefore, there is no difference between researchers according to specifying the error and they are in full (100\%) agreement. On this basis, there was no need to calculate inter-rater reliability.

The statistical errors were examined as: "p-values given in a closed form" (e.g., $\mathrm{p}<0.01, \mathrm{p}<0.05, \mathrm{p}>$ $0.05)$, "non-reported p-values", "incorrect p-values (which are related to frequency tables)", "incorrect demonstration of $\mathrm{p}$-values (e.g., $\mathrm{p}=0.000, \mathrm{p}<$ 0.0005 etc.)", "undefined statistical test", "insufficient data present for a statistical test", "incorrect name of a statistical test", "statistical technique defined but not used", "use of an incorrect test", "statistical analysis required but not performed", "errors in summarizing data" (it contains incorrect reporting regarding analyses, e.g., errors in percentages, incorrect presentation in table format, etc.), "mathematical demonstration errors (e.g., lacking demonstration of decimals, using ":" rather than "=")", "statistical symbol errors (e.g., using $\pi$ for a Chi-square value)", "incomprehensible statistical terms", "inappropriate interpretation", "errors in (statistical) terminology", "incorrect and insufficient demonstration of descriptive statistics" (it contains incorrect or inadequate reporting of descriptive statistics,.e.g., reporting mean and standard deviation when nonparametric test is applied, not reporting measure of variability with arithmetic mean, etc.) and "presentation of statistical method- analysis and results in the incorrect section of the manuscript". ${ }^{4}$

The percentage of statistical errors was calculated, taking into account the number of articles reviewed. Further, the potential difference between the statistical errors seen in articles indexed in SCI and SCI-E and in non-SCI or non-SCI-E journals was investigated using the Chi-square test and Fisher's exact test. The results of the study were presented as counts and their corresponding percentage values. Data were analyzed by SPSS software 20.0 (IBM SPSS Statistics for Windows, Version 20.0. Armonk, NY: IBM Corp.)

\section{RESULTS}

In the study, 217 articles, which included 95 SCI or SCI-E-indexed articles and 122 non-SCI or nonSCI-E articles were reviewed with regards to statistical errors. A total of 217 articles had at least one statistical error. Table 2 gives a detailed account of the distribution of statistical errors among the 217 articles,

The most frequently encountered statistical error was "errors in summarizing data" for articles published in journals indexed as either SCI or SCI-E and as non-SCI or non-SCI-E (Table 2).

For errors that involved "use of an incorrect test" and "statistical symbol errors", there was a statistically significant difference favoring the articles published in SCI or SCI-E journals over those in 
International Journal of Hematology and Oncology

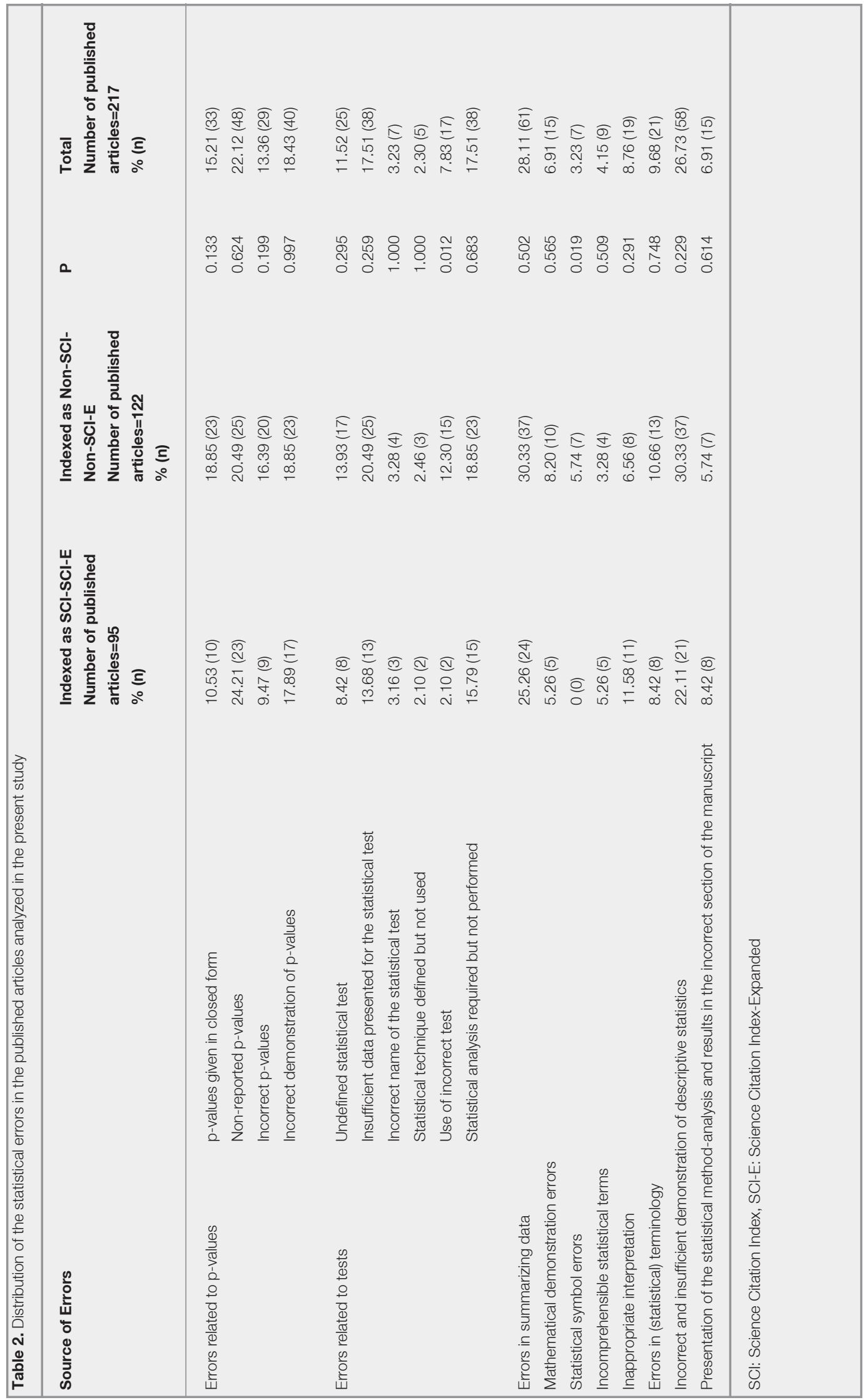


International Journal of Hematology and Oncology

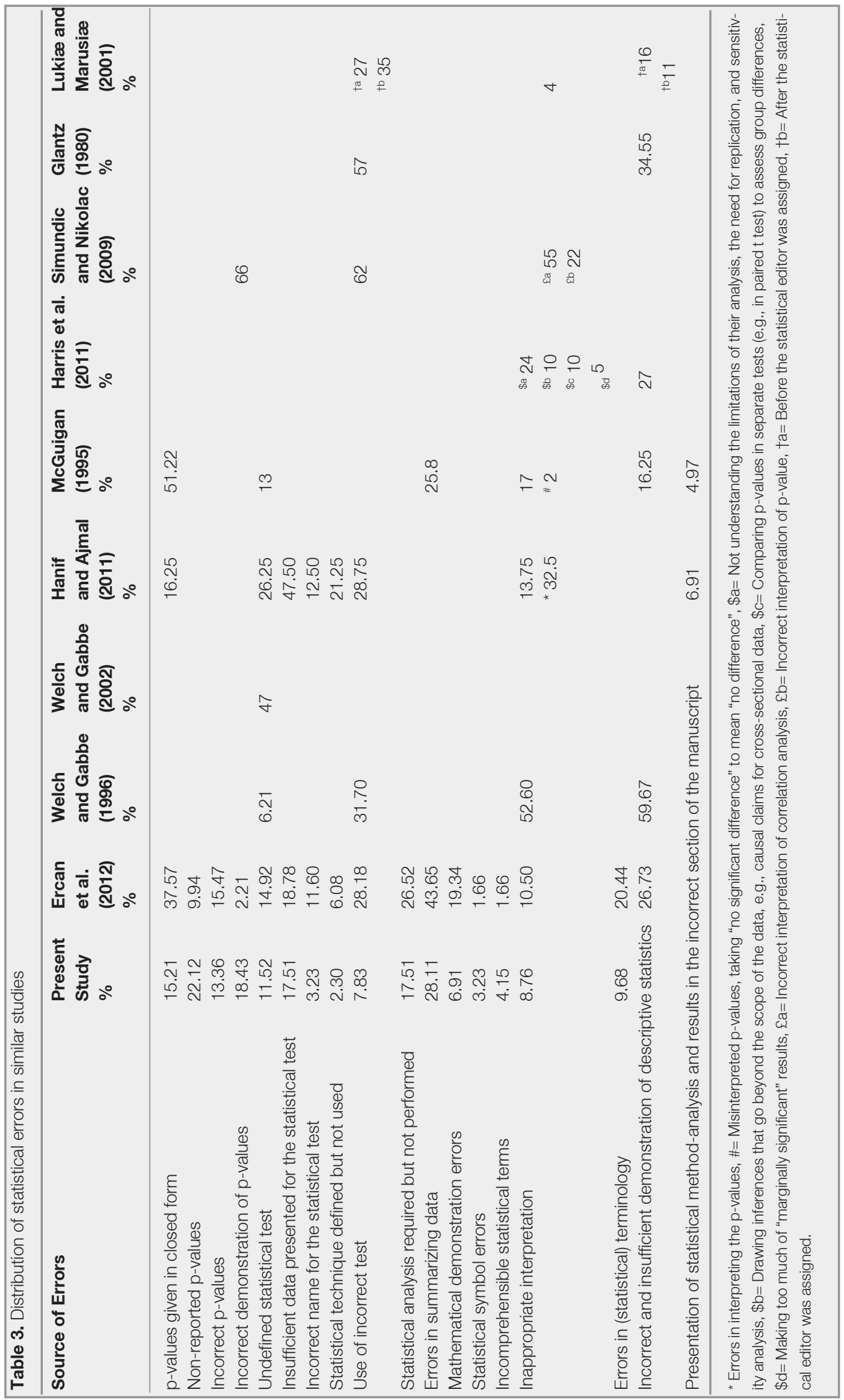


non-SCI or non-SCI-E journals (Table 2). Table 3 presents the findings of similar studies investigating the distribution of statistical errors.

\section{DISCUSSION}

In the present study, the statistical errors of the published articles were identified. This study differs from similar studies in the literature in terms of comparing articles which are published at journals indexed in SCI and SCI-E and journals indexed in different indices. It is intended to draw researchers' attention about nature of statistical errors and in which statistical topic there are more errors. For this purpose, division of the number of articles which have statistical errors by the number of articles which were examined was accepted as main criterion. It must be acknowledged that there is no unique definition of either "statistical error" or "statistical error rate", which makes the comparison of different statistical reviews difficult. ${ }^{7}$

When we evaluate the statistical errors that are committed in published articles in terms of their effects on the study results, we need to acknowledge the fact that some of the errors (i) Are directly pertinent to the results, some of them (ii) Occur in demonstration and terminology only and do not affect the results. ${ }^{12}$

When errors related to $\mathrm{p}$-values were investigated, "p-values given in closed forms" were found in $15.21 \%$ of articles $(10.53 \%$ SCI or SCI-E and $18.85 \%$ non-SCI or non-SCI-E). Hanif and Ajmal reported a similar percentage $(16.25 \%)$, while McGuigan reported a value of $51.22 \%$ in the review of published articles related to this type of statistical error. ${ }^{7,10}$ Some authors do not consider closed forms of $\mathrm{p}$-values to be erroneous. However, p-values given in an open form enables the use of published articles in meta-analyses. This presentation also helps us to determine statistical errors and to assess whether inappropriate statistical methods have been used, which might have generated inaccurate $\mathrm{p}$-values, during the review process of submitted manuscripts. Additionally, readers can obtain more information from open-form $p$ values; such p-values further prevent unethical applications of the data. ${ }^{13}$ Editors have started to request $\mathrm{p}$-values to prevent generalizations based on studies performed using small study groups over a long period of time. For instance, Dr. Franz J. Ingelfinger prohibited the use of the word "significant" without the inclusion of p-values during his career with The New England Journal of Medicine between 1967 and 1977. ${ }^{13-14}$

When other errors related to p-values were reviewed in the present study, it was found that $\mathrm{p}$ values were not provided after a statistical test in $22.12 \%$ of articles $(24.21 \%$ SCI or SCI-E and $20.49 \%$ non-SCI or non-SCI-E); incorrect p-values (which are related to frequency tables) were given in $13.36 \%$ of these $(9.47 \%$ SCI or SCI-E and $16.39 \%$ non-SCI or non-SCI-E); and $18.43 \%$ of the articles $(17.89 \%$ SCI or SCI-E and $18.85 \%$ nonSCI or non-SCI-E) demonsrated p-values incorrectly. In their similar study, Šimundić and Nikolac reported that p-values were reported incorrectly in $66 \%$ of the submitted manuscripts analyzed. ${ }^{2}$

In the present study, there was no significant difference between SCI or SCI-E and non-SCI or non-SCI-E articles according to the proportions of errors related to p-values. The number of errors related to $p$-values was found to be very high. Sub-groups of errors related to p-values, including "p-values given in closed form", "non-reported pvalues", "incorrect p-values" and "incorrect demonstration of p-values", yielded similar results. The error "incorrect p-values" has a remarkable potential to drastically affect the discussion section of a paper. The proportion of this type of error was also found to be very high.

Following the investigation of errors related to statistical tests in the present study, we found that an undefined statistical test was used in $11.52 \%$ of articles (8.42\% for SCI or SCI-E and $13.93 \%$ for non-SCI or non-SCI-E). In similar studies of published articles, Welch and Gabbe determined this rate to $6.21 \%$ in one report and $47 \%$ in another report. ${ }^{5-6}$ Hanif and Ajmal reported a value of $26.25 \%$, and McGuigan found a rate of $13 \%$. 7,10 The rate of insufficient results given concerning the statistical test performed was $17.51 \%$. (13.68\% for SCI or SCI-E and $20.49 \%$ for non-SCI or nonSCI-E) However, Hanif and Ajmal found this rate to be $47.50 \%$ in published articles. ${ }^{10}$ In the present study, $3.23 \%$ of the manuscripts included an 
incorrect name of a statistical test $(3.16 \%$ for SCI or SCI-E and $3.28 \%$ for non-SCI or non-SCI-E). In their similar study of published articles, Hanif and Ajmal reported this rate to be $12.50 \% .^{10}$ The rate of statistical techniques being defined but not used was $2.30 \%$ in the present study $(2.10 \%$ for SCI or SCI-E and $2.46 \%$ for non-SCI or non-SCIE); Hanif and Ajmal obtained a rate of $21.25 \%$. In our study, the rate of use of an incorrect test was $7.83 \% .{ }^{10}$ (2.10\% for SCI or SCI-E and $12.30 \%$ for non-SCI or non-SCI-E). Welch and Gabbe, Hanif and Ajmal and Glantz found rates of $31.70 \%$, $28.75 \%$ and $57 \%$, respectively. ${ }^{6,10-11}$ Lukiæ and Marušiæ calculated a rate of $27 \%$ before a statistical editor had been assigned; after the assignment of a statistical editor, the rate increased to $35 \% .8$ Šimundić and Nikolac reported this rate to be $62 \%$ in their similar study of manuscripts in the process of submission. ${ }^{2}$ In the present study, the rate of papers for which statistical analysis was required but not performed was $17.51 \%$ (15.79\% for SCI or SCI-E and $18.85 \%$ for non-SCI or non-SCI-E).

In the present study, there was a significant difference between SCI or SCI-E and non-SCI or nonSCI-E articles with respect to the proportions of errors related to tests. The proportion of errors related to tests in SCI or SCI-E articles was considerably higher than in non-SCI or non-SCI-E articles. In the sub-groups of errors related to tests, although there was no significant difference between SCI or SCI-E and non-SCI or non-SCI-E articles, regarding the proportions of "undefined statistical test", "insufficient data presented for the statistical test", "incorrect name for the statistical test", "statistical technique defined but not used" and "statistical analysis required but not performed", there was a significant difference in the proportion of "use of an incorrect test". The proportion of "use of an incorrect test" in the non-SCI or non-SCI-E articles was higher than in the SCI or SCI-E articles. This type of error has critical implications with regard to the papers' discussions.

In the present study, $28.11 \%$ of the articles included errors in summarizing data $(25.26 \%$ for SCI or SCI-E and $30.33 \%$ for non-SCI or non-SCI-E). McGuigan calculated this rate to be $25.8 \%$ in his study of published articles. ${ }^{7}$ Mathematical demonstration errors exhibited a rate of $6.91 \%$ in this study $(5.26 \%$ for SCI or SCI-E and $8.20 \%$ for non-SCI or non-SCI-E), while the rate of statistical symbol errors was $3.23 \%$ ( $0 \%$ for SCI or SCI$\mathrm{E}$ and $5.74 \%$ for non-SCI or non-SCI-E) and that of incomprehensible statistical terms was $4.15 \%$ (5.26\% for SCI or SCI-E and $3.28 \%$ for non-SCI or non-SCI-E).

The rate of inappropriate interpretation in the manuscripts was $8.76 \%$ (11.58\% for SCI or SCI-E and $6.56 \%$ for non-SCI or non-SCI-E). Welch and Gabbe found this rate to be $52.60 \%$, while Lukiæ and Marušiæ found it to be $4 \%$ in their studies of published articles. ${ }^{6,8}$ Hanif and Ajmal obtained a rate of $13.75 \%$ in published articles, while the rate of errors related to the interpretation of p-values was $32.5 \% .^{10}$ McGuigan reported this rate as $17 \%$ in a study of published articles but found a rate of errors related to the interpretation of $\mathrm{p}$-values of $2 \% .^{7}$ Harris et al. subcategorized the errors related to interpretation in their study of published articles. ${ }^{9}$ They found that $24 \%$ demonstrated "not understanding the limitations of their analysis, the need for replication and sensitivity analysis"; $10 \%$ exhibited "drawing inferences that go beyond the scope of the data", e.g., causal claims for crosssectional data; $10 \%$ that qualified as "comparing p-values of separate tests (e.g., paired t test) to assess group differences"; and 5\% that demonstrated "making too much of 'marginally significant' results". ${ }^{9}$ Simundić and Nikolac found that the rates of misinterpreting correlation analyses and their pvalues were $55 \%$ and $22 \%$ in their similar study of manuscripts in the submission process. ${ }^{2}$

The rate of errors in statistical terminology was $9.68 \%(8.42 \%$ for SCI or SCI-E and $10.66 \%$ for non-SCI or non-SCI-E) in our present study; $6.91 \%$ of the articles $(8.42 \%$ for SCI or SCI-Expanded and $5.74 \%$ for non-SCI or non-SCI-E) involved the inclusion of statistical method analyses and results in the wrong section of the paper.

In our study, $26.73 \%$ of the manuscripts included errors related to incorrect and insufficient demonstrations of descriptive statistics $(22.11 \%$ for SCI or SCI-Expanded and $30.33 \%$ for non-SCI or non-SCI-E). Hanif and Ajmal found this rate to be $16.25 \%$; McGuigan as $27 \%$; and Lukiæ and Marušiæ as $16 \%$ before the assignment of a sta- 
tistics editor and as $11 \%$ after review by a statistics editor. ${ }^{7-8,10}$ Šimundić and Nikolac reported this rate as $34.55 \%$ in submitted articles, similar to the value in our study. ${ }^{2}$

In our study, there was no difference between SCI or SCI-E and non-SCI or non-SCI-E articles with respect to their proportions of "errors in summarizing data", "mathematical demonstration errors", "statistical symbol errors", "incomprehensible statistical terms", "inappropriate interpretation", "errors in (statistical) terminology", "incorrect and insufficient demonstration of descriptive statistics" and "presentation of statistical method-analysis and results in the incorrect section of the manuscript", but a significant difference was detected regarding the proportions of "statistical symbol errors". Statistical symbol errors were not observed in SCI or SCI-E articles, while non-SCI or nonSCI-E articles included this type of error.

Thus, we have shown that statistical errors are frequently encountered in scientific publications. Among studies related to this issue, the proportions of these statistical errors differ considerably. The reason for this variance is thought to be different approaches to grouping error types. As a result, although the proportions of errors may be small, these errors will have a considerably negative impact on the studies' results.

Using inappropriate statistical methods, techniques and analyses could be a waste of time and financial resources, and most importantly, considering scientific ethics, it is detrimental to the scientific concepts and to humanity. Even when a study is carefully planned, the use of incorrect statistical approaches may produce misleading, suboptimal, incoherent results that are amenable to being cited by other researchers. ${ }^{3}$

At the publication stage, the last stage of a study, which has been reached after overcoming huge difficulties, three fundamental negative situations can ensue regarding possible negative effects of errors: (i) Publications with statistical errors induce a negative effect on science and mankind. (ii) When these errors are identified during the reviewers' assessment, they will cause a loss of academic confidence in the study, leading to an early rejection. (iii) Statistical errors in published articles are likely to cause a loss of an author's academic credibility. ${ }^{12}$

Statistical errors in scientific studies are often specified in an authors' declaration. However, whether these authors also made statistical mistakes in the parts of the study they did not declare is unknown. We believe that similar mistakes are made by authors in these parts of their studies. Therefore, further studies should be conducted with the purpose of exploring this type of error in these studies.

Studies concerning the specification of statistical errors in scientific studies in medicine are conducted to call the attention of researchers and editors to this issue and to emphasize the importance of a proper biostatistics education. Some actions must be taken by researchers and editors to prevent the inclusion of such statistical errors in scientific publications. Researchers (i) should have a basic statistical knowledge and (ii) should consult a biostatistician in the planning, analyzing, interpreting and reporting stages of a study. Furthermore, editors should send studies that have been submitted to their journal to a biostatistician during the review process.

\section{REFERENCES}

1. Ercan I, Ocakoglu G, Ozkaya G, Sigirli D, Cangur S, Gunel Karadeniz P. An International Survey of Physicians' Knowledge of Biostatistics. Turkiye Klinikleri J Med Sci 33: 401-409, 2013.

2. Simundic AM, Nikolac N. Statistical Errors in Manuscripts Submitted to Biochemia Medica Journal. Biochem Med 19: 294-300, 2009.

3. Ercan I, Yazici B, Yang Y, Ozkaya G, Cangur S, Ediz B, et al. Misusage of Statistics in Medical Research. Eur J Gen Med 4: 128-134, 2007.

4. Ercan I, Ocakoglu G, Sigirli D, Ozkaya G. Assessment of Submitted Manuscripts in Medical Sciences According to Statistical Errors. Turkiye Klinikleri J Med Sci 32: 1381-1387, 2012.

5. Welch II GE, Gabbe SG. Statistics Usage in the American Journal of Obstetrics and Gynecology: Has Anything Changed? Am J Obstet Gynecol 186: 584-586, 2002.

6. Welch II GE, Gabbe SG. Review of Statistics Usage in the American Journal of Obstetrics and Gynecology. Am J Obstet Gynecol 175: 1138-1141, 1996.

7. McGuigan S. The Use of Statistics in the British Journal of Psychiatry. Brit J Psychiat 167: 683-688, 1995. 
8. Lukiæ IK, Marusiæ M. Appointment of Statistical Editor and Quality of Statistics in a Small Medical Journal. Croat Med J 42: 500-503, 2001.

9. Harris A, Reeder R, Hyun J. Survey of Editors and Reviewers of High-Impact Psychology Journals: Statistical and Research Design Problems in Submitted Manuscripts. J Psychol 145: 195-209, 2011.

10. Hanif A, Ajmal T. Statistical Errors in Medical Journals (a Critical Appraisal). Annals of KEMU 17: 178-182, 2011.

11. Glantz SA. Biostatistics: How to Detect, Correct and Prevent Errors in the Medical Literature. Circulation 61: 1-7, 1980.

12. Ercan I, Demirtas H. Statistical Errors in Medical Publication. Biom Biostat Int J 2: 00021, 2015.

13. Ercan I. Letter to the Editor: $p$-degeri acik mi kapali mi yazilmali? [Should P-Values Be Written in the Open or Closed Form?]. J Pediatr Inf 4: 47, 2010.

14. Feinstein AR. Common Faults in Biostatistics in Medical Research. Scientific writing, editing and auditing in medicine symposium. Ankara: Tubitak Health Sciences Research Group 1994; 49-55.

\section{Correspondence}

Dr. Ilker ERCAN

Uludağ Üniversitesi Tıp Fakültesi

Biyoistatistik Anabilim Dalı

Nilufer

BURSA / TURKEY

Tel: (+90-224) 2953888

email: ercan@uludag.edu.tr 